\title{
Isolasi dan Karakteristik Bakteri Pendegradasi Selulosa dari Limbah Pusat Industri Mebel Antang Makassar
}

\author{
Fahruddin Fahruddin
}

\begin{abstract}
Departemen Biologi, Fakultas Matematika dan Ilmu Pengetahuan Alam, Universitas Hasanuddin, Makassar
\end{abstract}
*Koresponden email: fahruddin_science@unhas.ac.id

Diterima: 24 Januari 2020

Disetujui: 14 Februari 2020

\begin{abstract}
Antang Furniture Center in Makassar is one of the wood industries and is still traditionally. The wood processing produces waste containing cellulose that is difficult to degrade. This study aims to isolate and observe the characteristics of cellulose degrading bacteria. This research was conducted at the Microbiology Laboratory, Faculty of Mathematics and Natural Sciences, Hasanuddin University, Makassar from March 2019 to November 2019. The method used was an experimental laboratory consisting of Carboxyl Methyl Cellulose (CMC) media for bacterial selection and characterization including microscopic morphology with Gram staining and morphology macroscopic with colony structure. The results showed that cellulose degrading bacteria were characterized by the formation of clear zones formed on CMC media in petri dishes. Based on macroscopic and microscopic morphological characteristics, eleven types of cellulose degrading bacteria isolates were obtained. The isolates obtained can be a source of bacterial isolates for further application in wood waste or other wastes that contain of cellulose.
\end{abstract}

Keywords: bacteria, cellulose, characteristic, degradation, enzyme cellulase, wood waste

\begin{abstract}
Abstrak
Pusat Mebel Antang Makassar merupakan salah satu industri pengolahan kayu yang besar dan masih dikelola secara tradisional. Industri pengolahan kayu tersebut menghasilkan limbah yang mengandung selulosa sulit terdegradasi. Penelitian ini bertujuan untuk mengisolasi dan mengamati karakteristik bakteri pendegradasi selulosa. Penelitian ini dilaksanakan di Laboratorium Mikrobiologi, Fakultas Matematika dan Ilmu Pengetahuan Alam, Universitas Hasanuddin, Makassar dari Maret 2019 sampai November 2019. Metode yang digunakan adalah eksperimental laboratorium yang terdiri atas CMC media untuk seleksi dan karakterisasi bakteri (meliputi morfologi mikroskopis dengan pewarnaan Gram dan morfologi makroskopis dengan ciri kolon). Hasil penelitian menunjukkan bahwa diperoleh bakteri pendegradasi selulosa ditandai dengan terbentuknya zona bening yang terbentuk pada media CMC di cawan petri. Berdasarkan karakteristik morfologi secara makroskopis dan mikroskopis diperoleh sebelas jenis isolat bakteri pendegradasi selulosa. Isolat yang diperoleh dapat menjadi sumber isolat bakteri untuk diaplikasikan lebih lanjut pada limbah kayu ataupun limbah lainnya yang mengandung banyak selulosa.
\end{abstract}

Kata Kunci: bakteri, selulosa, karakeristik, degradasi, enzim selulase, limbah kayu.

\section{Pendahuluan}

Salah satu jenis bahan organik yang banyak terdapat di bumi adalah selulosa (sekitar 40-50\% dalam tubuh tumbuh-tumbuhan). Selulosa merupakan karbohidrat yang tergolong polisakarida [1][2]. Sebagai polimer glukosa, selulosa dihubungkan oleh ikatan B-1,4-glikosida yang membentuk polimer rantai lurus. Struktur selulosa ini sangat sulit larut dalam air maupun dalam bahan-bahan pelarut yang biasa digunakan. Hidrolisa selulosa hanya dapat dilakukan dengan pelarut asam mineral kuat atau hidrolisis asam dan dengan menggunakan enzim atau hidrolisis enzimatis [3].

Proses degradasi selulosa dapat dilakukan secara enzimatik dengan bantuan mikroorganisme. Mikroorganisme yang dapat mendegradasi selulosa dikenal dengan mikroorganisme selulotik. Bakteri merupakan salah satu jenis mikroorganisme yang mampu mendegradasi selulosa dan memiliki kelimpahan terbanyak di alam dibanding mikroorganisme lainnya [4].

Hidrolisis enzimatis pada selulosa hanya dapat dilakukan oleh enzim yang disebut sebagai enzim selulase. Enzim ini diproduksi oleh banyak spesies dari golongan jamur maupun bakteri. Adanya produksi enzim ini menyebabkan banyak jenis jamur dan bakteri dapat hidup pada substrat yang mengandung selulosa sebagai sumber karbon [3][5]. 
Selulosa juga banyak terdapat pada limbah pengolahan kayu. Kayu mengandung kurang lebih 40$50 \%$ selulosa [6]. Seiring dengan meningkatnya penggunaan kayu untuk kebutuhan papan, maka pengolahan kayu memegang peran yang sangat penting. Pengolahan ini akan menghasilkan limbah yang banyak mengandung selulosa, dan terus meningkat sesuai dengan jumlah kebutuhan yang semakin meningkat pula [7]. Bahan selulosa terdapat secara alami berupa yang melimpah, bersifat biokompatibel, serta ramah lingkungan karena mudah mengalami penguraian di lingkungan. Selain itu, senyawa selulosa tidak toksik pada organisme dan dapat diperbaharui. Secara kimiawi selulosa merupakan polimer hidrofilik terdapat tiga gugus hidroksil reaktif. Setiap unit hidroglukosa terdiri dari ribuan gugus anhidroglukosa yang berhubungan pada ikatan 1,4-glukosida. Hal ini akan membentuk molekul berantai yang panjang dan linear [5]. Kehadiran selulosa di lingkungan adalah bercampur dengan lignin membentuk lignoselulosa, sehingga terdapat dalam jaringan kayu bersamaan dengan hemiselulosa pati dan lignin. Kombinasi anatara selulosa, hemiselulosa, dan lignin disebut lignoselulosa. Selulosa termasuk polisakarida terbanyak yang ditemukan pada tanaman, untuk mendegradasi selulosa memerlukan enzim selulase yang berasal dari mikroorganisme yang dapat menghasilkan enzim selulase [3].

Di Makassar terdapat industri mebel yang menghasilkan cukup banyak limbah kayu yang mengandung banyak bahan selulosa dikenal adalah Pusat Industri Mebel Antang. Berdasarkan hal tersebut, maka perlu dilakukan isolasi terhadap bakteri-bakteri yang mampu mengurai selulosa secara enzimatis, khususnya dari limbah yang banyak mengandung selulosa seperti limbah kayu yang terdapat pada Pusat Mebel di Antang, Makassar.

\section{Metodologi Penelitian \\ Tempat Penelitian}

Penelitian ini dilaksakan di Laboratorium Mikrobiologi, Fakultas Matematika dan Ilmu Pengetahuan Alam, Universitas Hasanuddin, Makassar dari Maret 2019 sampai November 2019.

\section{Pengambilan Sampel}

Sampel berupa limbah dari pengolahan kayu (serbuk halus) di Pusat Mebel Kayu Antang, Makassar diambil dengan menggunakan sendok steril dan kemudian dimasukkan ke dalam botol sampel yang sudah disterilkan, ditutup rapat untuk dilakukan pemeriksaan lebih lanjut.

\section{Inokulasi dan Isolasi}

Sampel ditimbang sebanyak 10 gram dan dilarutkan dalam $90 \mathrm{ml}$ aquades dan diencerkan hingga $10^{-2}$. Kemudian dihomogenkan dan dimasukkan secara aseptis ke dalam 4 tabung reaksi berisi medium enrichment dengan menggunakan spoit steril sebanyak masing-masing $1 \mathrm{ml}$ sampel. Dari tabung berisi medium enrichment bakteri yang menunjukkan adanya pertumbuhan bakteri yang ditandai dengan terjadinya perubahan medium menjadi keruh serta kerusakan pada kertas saring, diambil masing-masing satu ose biakan secara aseptis untuk diinkubasikan dalam medium enrichment dengan menggunakan metode taburan. Setelah itu diinkubasikan pada suhu $37{ }^{\circ} \mathrm{C}$ sampai terlihat adanya pertumbuhan koloni bakteri. Komposisi medium enrichment yaitu $\left(\mathrm{NH}_{4}\right)_{2} \mathrm{SO}_{4}, \mathrm{~K}_{2} \mathrm{HPO}_{4}, \mathrm{MgSO}_{4} .7 \mathrm{H}_{2} \mathrm{O}, \mathrm{CaCl}_{2} .2 \mathrm{H}_{2} \mathrm{O}, \mathrm{FeCl}_{3}$ dalam $1000 \mathrm{ml}$ akuades.

\section{Pemilahan Bakteri Pendegradasi Selulosa}

Dari tiap koloni bakteri yang tumbuh dan menunjukkan perbedaan pada medium selektif diambil sebanyak satu ose secara aseptis kemudian diinkubasikan kembali pada medium selektif dengan cara goresan dan diinkubasikan pada suhu $37{ }^{\circ} \mathrm{C}$ selama 1x24 jam. Prosedur ini dilakukan beberapa kali sampai benar-benar diperoleh koloni bakteri yang terpisah dan murni. Komposisi medium selektif adalah $\left(\mathrm{NH}_{4}\right)_{2} \mathrm{SO}_{4}, \mathrm{~K}_{2} \mathrm{HPO}_{4}, \mathrm{MgSO}_{4} \cdot 7 \mathrm{H}_{2} \mathrm{O}, \mathrm{CaCl}_{2} \cdot 2 \mathrm{H}_{2} \mathrm{O}, \mathrm{FeCl}_{3}$ dan agar dalam 1000 akuades. Isolat yang pendegradasi selulosa memperlihatkan zona pertumbuhan yang bening.

\section{Pengamatan Morfologis}

Setelah diperoleh koloni bakteri yang terpisah dan telah murni dilakukan pengamatan morfologis, selanjutnya tiap-tiap isolat digores ke agar miring dan diinkubasikan pada suhu $37{ }^{\circ} \mathrm{C}$ selama $1 \times 24$ jam. Selanjutnya dilakukan pewarnaan gram pada masing-masing isolat bakteri.

\section{Hasil dan Pembahasan}

Perhitungan koloni bakteri dengan metode Standart Plate Count (SPC) mengacu pada Ref. [8] yang dilakukan dengan cara mengamati semua koloni yang tumbuh pada permukaan media agar. Berdasarkan hasil pengamatan pada media Plate Count Agar (PCA), terdapat 315 koloni bakteri yang tumbuh pada pengenceran $10^{-5}$, 176 koloni bakteri pada pengenceran $10^{-6}$, dan 43 koloni pada pengenceran $10^{-7}$. Berdasarkan pada perhitungan SPC dan didapatkan nilai $1,7 \times 10^{8} \mathrm{CFU} / \mathrm{ml}$. Bakteri yang tumbuh tersebut bukan hanya bakteri selulolitik karena medium pertumbuhan yang digunakan adalah media umum PCA. 
Hasil pengamatan koloni bakteri pada media PCA dapat dilihat pada Gambar 1.
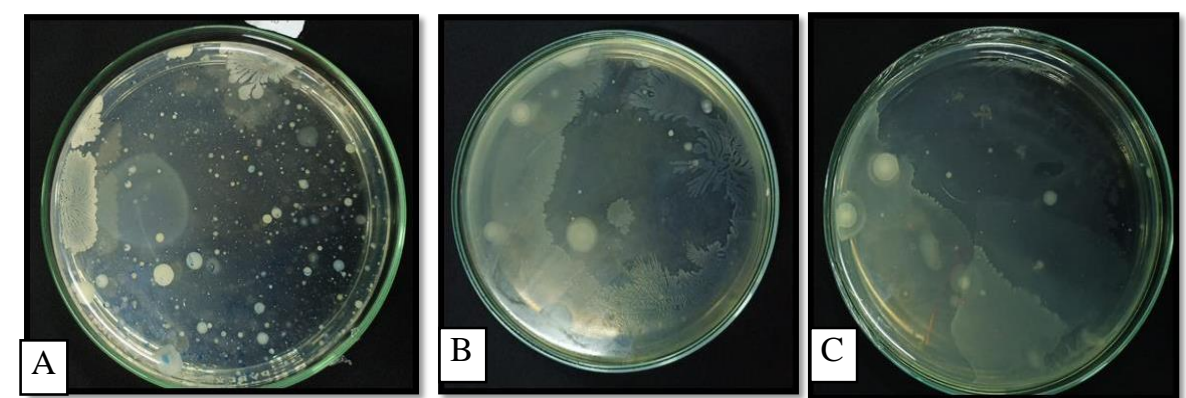

Gambar 1. Pertumbuhan bakteri selulolitik pada media agar PCA pada pengenceran: (A) $10^{-5}$, (B 10 $0^{-6}$, dan (C) $10^{-7}$ Sumber: Hasil penelitian (2019)

\section{Seleksi Bakteri Pendegradasi Selulosa}

Bakteri yang tumbuh pada media Carboxyl Methyl Cellulose (CMC) berwarna merah dan dikelilingi oleh zona bening. Zona bening tersebut dapat diindikasikan sebagai kemampuan suatu bakteri untuk menghidrolisis selulosa [7]. Pada Gambar 2, kultur bakteri yang mempunyai aktifitas enzim selulase yang tinggi dapat mengurai substrat selulosa menjadi senyawa sederhana glukosa dengan indikator adanya zona bening yang terbentuk di sekeliling koloni [9]. Hal ini terkait perubahan struktur selulosa berserat menjadi glukosa mempuyai struktur non serat [10]. Media CMC yang terurai oleh enzim selulase jika ditetesi oleh indikator congo red tak terwarnai. Ikatan ini terjadi dengan cara non-kovalen. Hal ini menunjukkan ada proses degradasi $\beta$-D-glukan pada media agar. Warna merah juga menunjukan adanya sisa selulosa yang tidak terhidrolisis. Congo red adalah garam natrium dari benzidinediazo-bis-1 naphthylamine-4 asam sulfonat sehingga zat ini akan terlarut dan tercuci oleh garam natrium lain, seperti $\mathrm{NaCl}[11]$.
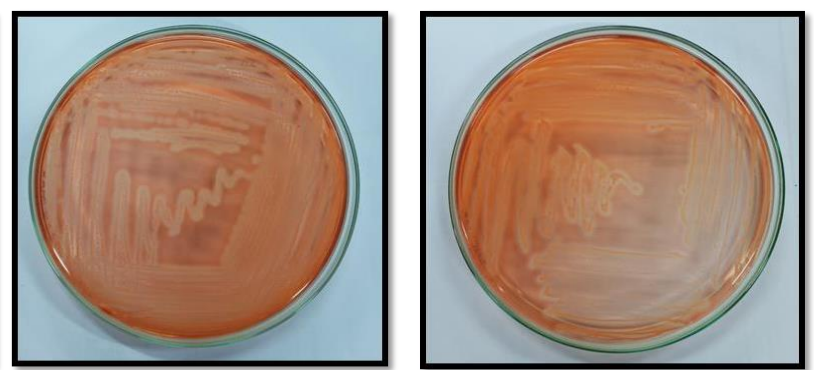

Gambar 2. Isolat bakteri selulolitik yang dikulturkan pada media CMC agar Sumber: Hasil penelitian (2019)

\section{Indeks aktivitas selulolitik}

Uji indeks aktivitas selulolitik yang dilakukan dengan menumbuhkan kembali koloni bakteri terpisah menggunakan teknik gores. Pada tahap pemurnian ini, digunakan metode titik dan diinkubasi selama 3x24 jam sehingga terlihat adanya zona bening yang terbentuk. Zona bening yang dihasilkan oleh bakteri selulolitik yang berdiameter diatas $4 \mathrm{~cm}$ dapat dikategorikan tingkat degradasi yang dihasilkan tinggi, sedangkan degradasi rendah berada pada kisaran 0,5-1,9 $\mathrm{cm}$ dan sedang 2,0-3,9 $\mathrm{cm}$ [9]. Berdasarkan hasil pengamatan, zona bening yang diperoleh untuk isolat A sebesar 1,8 cm dan isolat B sebesar 1,55 cm, kedua isolat ini dikategorikan memiliki tingkat degradasi yang rendah (Gambar 3).
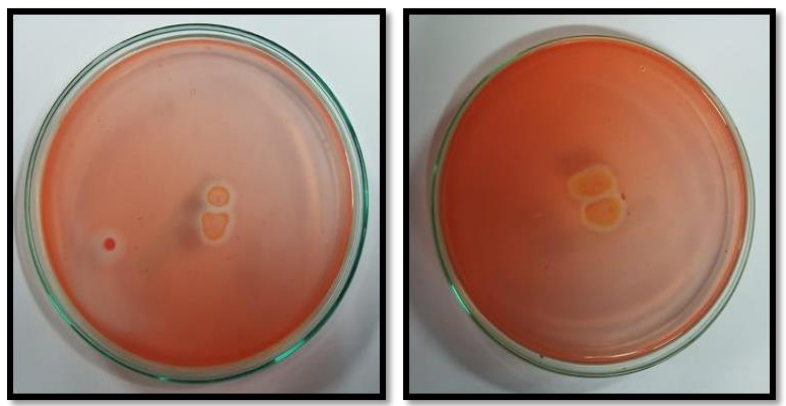

Gambar 3. Indeks aktivitas seluloliti: (a) Isolat bakteri A, (b) Isolat bakteri B

Sumber: Hasil penelitian (2019) 
Perbedaan nilai indeks aktivitas selulolitik yang didapatkan pada isolat A dan B adalah karena mengsekresikan enzim selulase oleh isolat bakteri memiliki potensi yang berbeda untuk menghidrolisis substrat yang terdapat dalam media pertumbuhan. Indeks selulase menunjukkan besarnya indeks selulase pada isolat diikuti pula besarnya aktifitas selulolitik yang dihasilkan [12].

Adanya bakteri yang mampu tumbuh pada medium ini menunjukkan bahwa bakteri tersebut mempunyai kemampuan menguraikan selulosa, sebab dalam medium enrichment yang digunakan sumber karbon satu-satunya adalah selulosa. Dengan demikian dapat diasumsikan bahwa bakteri yang tumbuh pada medium enrichment tersebut adalah bakteri pendegradasi selulosa [13].

Untuk memperkuat dugaan bahwa bakteri yang tumbuh adalah bakteri pendegradasi selulosa, maka bakteri tersebut diisolasi kembali pada medium selektif padat yang komposisinya sama dengan medium enrichment akan tetapi sumber selulosa yang digunakan adalah Carboxy Methyl Cellulosa (CMC) $1 \%$. Medium ini mempunyai formulasi yang dimodifikasi sehingga selektif untuk bakteri pengguna selulosa sebagai sumber karbon. Pertumbuhan pada medium selektif ini ditunjukkan oleh adanya koloni-koloni yang mempunyai beberapa ciri yang berbeda berdasarkan pada ciri morfologinya.

Substrat Carboxyl Methyl Cellulose (CMC) yang terkandung dalam media pertumbuhan bakteri selulolitik dapat diurai melalui bioakatalisator yaitu enzim selulase atau disebut CMCase. Bakteri yang memiliki kemampuan tumbuh pada media tersebut membuktikan isolat bakteri tersebut adalah bakteri selulolitik. Media CMC mengandung selulosa yang dumanfaatkan oleh bakteri selulolitik untuk sumber karbon pada pertumbuhannya. CMC merupakan turunan selulosa yang memiliki peran penting dan berguna sebagai agen pengemulsi, agen pensuspensi, dan sebagai pengikat dalam pembuatan tablet. Oleh karena itu, CMC telah banyak digunakan bidang industri seperti tekstil, obat-obatan, makanan, elemen listrik dan pembuatan kertas. Struktur Carboxyl Methyl Cellulose (CMC) merupakan rantai polimer yang terdiri dari unit molekul selulosa. Setiap unit anhidroglukosa memiliki tiga gugus hidroksil dan beberapa atom hidrogen dari gugus hidroksil tersebut disubstitusi oleh carboxymethyl [3].

Adanya bakteri yang tumbuh pada medium enrichment maupun medium selektif, menunjukkan bahwa bakteri-bakteri tersebut mampu menggunakan selulosa sebagai sumber karbon, dengan demikian mampu mendegradasi selulosa. Hal ini disebabkan karena selulosa merupakan senyawa polimer kompleks yang tidak dapat langsung digunakan oleh mikroorganisme sehingga harus diuraikan terlebih dulu menjadi molekul-molekul yang lebih sederhana [14].

Proses perombakan selulosa tersebut melalui mekanisme bahwa enzim selulase yang dihasilkan dalam sel tetapi merupakan enzim ekstrakseluler selanjutnya pada pada media pertumbuhannya dikeluarkan. Enzim selulase dapat merombak ikatan $\beta$-1,4-glikosidik. Berdasarkan hal ini, maka enzim selulase dapat dibagai menjadi tiga komponen, yaitu endo-1,4- $\beta$-D-glukanase, ekso -1,4- $\beta$-D-glukanase, dan $\beta$-D-glukosidase. Ketiga pada kelompok enzim tersebut dapat terjadi sinergisme dalam mengurai substrat selulosa menjadi glukosa. Adapun mekanisme kerja enzim selulase dalam merombak selulosa, terlihat dari terjadinya perubahan komposisi karbohidrat (nilai gula total, gula pereduksi, derajat polimerisasi dan dekstrosa ekuivalen) dalam substrat selama waktu tertentu [3].

\section{Karakterisik Bakteri Pendegradasi Selulosa}

Berdasarkan karakteristik morfologi yang meliputi warna, tepi, elevasi, struktur dalam, sifat gram, dan bentuk sel koloni, didapatkan 11 jenis isolat (Tabel 1). Dari ke-11 isolat yang didapatkan, isolat B, C, dan I memperlihatkan pertumbuhan yang lebih cepat pada medium selektif dibandingkan dengan isolat yang lain, yaitu kurang dari 24 jam, sedangkan isolat yang lain memperlihatkan pertumbuhannya setelah lewat dari 24 jam.

Berdasarkan hasil pengamatan morfologi pada Tabel 1 menunjukkan bahwa ke-11 isolat yang diperoleh mempunyai bentuk koloni yang sama yaitu bentuk bulat (circular), sedangkan warna koloni bervariasi yaitu kuning muda untuk isolat $\mathrm{A}, \mathrm{B}, \mathrm{E}, \mathrm{H}$, dan $\mathrm{J}$, warna putih untuk isolat $\mathrm{C}, \mathrm{F}$ dan $\mathrm{G}$, berwarna putih kekuningan untuk isolat I dan ada koloni yang tidak menampakkan warna pada medium (bening) didapatkan pada isolat $\mathrm{D}$ dan $\mathrm{L}$. Pengamatan pada tepi koloni menunjukkan bahwa untuk isolat A, B, D, E, J, dan K mempunyai tepi koloni yang rata (entire), isolat C, F, G, dan I tepi koloninya bersilia (ciliate) sedangkan pada isolat $\mathrm{H}$ tepi koloninya bergelombang (lacerate). Untuk elevasi koloni, didapatkan koloni yang elevasinya cembung (convex) yaitu pada isolat $\mathrm{B}$ dan $\mathrm{F}$, agak cembung (low convex) pada isolat A, C, D, E, I, J dan $\mathrm{K}$, sedangkan untuk isolat $\mathrm{G}$ dan $\mathrm{H}$ elevasi koloninya rata (effuse). 
Tabel 1. Ciri morfologi isolat bakteri pendegradasi selulosa

\begin{tabular}{|c|c|c|c|c|c|c|c|}
\hline Isolat & $\begin{array}{l}\text { Bentuk } \\
\text { Koloni }\end{array}$ & $\begin{array}{l}\text { Warna } \\
\text { Koloni }\end{array}$ & $\begin{array}{c}\text { Tepi } \\
\text { Koloni }\end{array}$ & $\begin{array}{l}\text { Elevasi } \\
\text { Koloni }\end{array}$ & $\begin{array}{c}\text { Struktur } \\
\text { Dalam }\end{array}$ & Gram & $\begin{array}{c}\text { Bentuk } \\
\text { Sel }\end{array}$ \\
\hline A & bulat & $\mathrm{km}$ & rata & $\mathrm{AC}$ & TC & neg. & bulat \\
\hline B & bulat & $\mathrm{km}$ & rata & $\mathrm{C}$ & TTC & neg. & btpd \\
\hline $\mathrm{C}$ & bulat & pth & bsl & $\mathrm{AC}$ & TTC & neg. & btpd \\
\hline $\mathrm{D}$ & bulat & bng & rata & $\mathrm{AC}$ & $\mathrm{TC}$ & neg. & bulat \\
\hline $\mathrm{E}$ & bulat & $\mathrm{km}$ & rata & $\mathrm{AC}$ & TCS & neg. & bulat \\
\hline $\mathrm{F}$ & bulat & pth & bsl & $\mathrm{C}$ & Flmt. & neg. & bulat \\
\hline $\mathrm{G}$ & bulat & pth & bsl & RT & TCS & neg. & bulat \\
\hline $\mathrm{H}$ & bulat & $\mathrm{km}$ & bglb & RT & TCS & neg. & bulat \\
\hline I & bulat & pk & bsl & $\mathrm{AC}$ & TTC & neg. & bulat \\
\hline $\mathrm{J}$ & bulat & $\mathrm{km}$ & rata & $\mathrm{AC}$ & TCS & neg. & bulat \\
\hline $\mathrm{K}$ & bulat & bng & rata & $\mathrm{AC}$ & $\mathrm{TC}$ & neg. & btpd \\
\hline
\end{tabular}

Sumber: Hasil penelitian (2019)

Ada beberapa struktur dalam koloni yang didapatkan, yaitu pada isolat $\mathrm{A}, \mathrm{D}$, dan $\mathrm{K}$ adalah tembus cahaya (transparant), isolat $\mathrm{G}, \mathrm{H}$, dan $\mathrm{J}$ adalah tembus cahaya sebagian (translucent), isolat B, C, dan I adalah tidak tembus cahaya (opaque) dan untuk isolat $\mathrm{F}$ struktur dalamnya adalah filamen (filamentous).

Pengamatan bentuk sel bakteri yang dilakukan dengan menggunakan mikroskop, didapatkan 2 (dua) bentuk sel yaitu bentuk batang pendek untuk isolat B, C, dan K, dan bentuk sel bulat didapatkan pada isolat A, D, E, F, G, H, I, dan J. Sedangkan hasil pengamatan pada pengecatan gram didapatkan bahwa semua koloni yang didapatkan menunjukkan sifat gram negatif yaitu bahwa dinding sel bakteri tidak mampu mengikat zat warna kristal violet tetapi mampu mengikat (menyerap) zat warna safranin [15].

\section{Kesimpulan}

Dari hasil penelitian ini dapat disimpulkan bahwa pada limbah industri kayu di Antang Makassar terdapat bakteri pendegradasi selulosa berdasarkan hasil pemilahan menggunakan medium Carboxy Methyl Cellulose (CMC) ditandai dengan terbentuknya zona bening. Berdasarkan karakteristik morfologi secara makroskopis dan mikroskopis diperoleh sebelas jenis isolat bakteri pendegradasi selulosa.

\section{Singkatan}

$\begin{array}{ll}\text { km } & \text { kuning muda } \\ \text { pth } & \text { putih } \\ \text { bng } & \text { bening } \\ \text { pk } & \text { putih kekuningan } \\ \text { bsl } & \text { bersilia } \\ \text { bglb } & \text { bergelombang } \\ \text { C } & \text { cembung } \\ \text { AC } & \text { agak cembung } \\ \text { RT } & \text { rata } \\ \text { TC } & \text { tembus cahaya } \\ \text { TCS } & \text { tembus cahaya sebagian } \\ \text { Flmt. } & \text { filamen } \\ \text { btpd } & \text { batang pendek } \\ \text { neg. } & \text { gram negatif }\end{array}$

\section{Referensi}

[1] S. R. Adawiyah, Fahruddin, dan K. Mustari, "Aplikasi isolat bakteri dari TPA Tamangapa Makassar dalam proses pengomposan sampah organik rumah tangga," Celebes Biodiversitas, vol. 1, pp. 40-44, 2017.

[2] A. Andriany, F. Fahruddin, dan A. Abdullah, "Pengaruh jenis bioaktivator terhadap laju dekomposisi seresah daun jati Tectona grandis L.f., di wilayah Kampus Unhas Tamalanrea," Bioma: Jurnal Biologi Makassar, vol. 3, pp. 31-42, 2018.

[3] P. Bajpai,“Application of enzymes in the pulp and paper industry," Biotechnol. Prog., vol. 15, pp. 147-157, 1999. 
[4] K. Septiningrum, dan I. Pramuaji, "Aplikasi enzim di industri pulp dan kertas: I. bidang pulp," Jurnal Selulosa, vol. 7, pp. 1-16, 2017.

[5] S. A. Yogyaswari, M. I. Rukmi, dan B. Raharjo, "Ekplorasi bakteri selulolitik dari cairan rumen sapi Peranakan Fries Holland (PFH) dan Limousine Peranakan Ongole (Limpo)," Jurnal Biologi, vol. 5, pp. 70-80, 2016.

[6] D. Fengel, dan G. Wejener, Kayu: Kimia, Ultrastruktur dan Reaksi-reaksi. Yogyakarta: Gajah Mada University Press, 1995.

[7] H. R. Gohel, C. N. Contractor, S. K. Ghosh, and V. J. Braganza, “A comparative study of various staining techniques for determination of extra cellular cellulase activity on Carboxy Methyl Cellulose (CMC) agar plates," Int. J. Curr. Microbiol. App. Sci., vol. 3, pp. 261-266, 2014.

[8] A. Margarida, S. Idalina, M. Ana, N. Maria, O. Pereira, "Improvements on colony morphology identification towards bacterial profiling," J. Microbiol. Methods. Vol. 95, pp. 327-335, 2013.

[9] H. Setyoko, dan B. Utami, "Isolasi dan karakteristik enzim selulase cairan rumen sapi untuk hidrolisis biomassa," Proceeding Biology Education Conference, vol. 13, pp. 863-867, 2016.

[10] D. Monariqsa, N. Oktora, A. Azora, D. A. N. Haloho, L. Simanjuntak, A. Musri, A. Saputra, dan A. Lesbani, "Ekstraksi selulosa dari kayu gelam (Melaleuca leucadendron Linn) dan kayu serbuk industri mebel," Jurnal Penelitian Sains, vol. 15, pp. 96-101, 2012.

[11] J. Hegner, K. C. Pereira, B. DeBoef, and B. L. Lucht, "Conversion of cellulose to glucose and levulinic acid via solid-supported acid catalysis," Tetrahedron Lett., vol. 51, pp. 2356-2358, 2010.

[12] H. Murtiyaningsih, dan M. Hazmi, "Isolasi dan uji aktivitas enzim selulase pada bakteri selulolitik asal tanah sampah," Agritrop, vol. 15, pp. 293-308, 2017.

[13] P. N. Trisanti, S. Setiawan, E. Nura'ini, dan S. Sumarno, "Ekstraksi selulosa dari serbuk gergaji kayu sengon melalui proses delignifikasi alkali ultrasonik," Jurnal Sains Materi Indonesia, vol. 19, pp. 113-119, 2018.

[14] N. Kamal, "Pengaruh bahan aditif CMC (Carboxyl Methyl Cellulose) terhadap beberapa parameter pada larutan sukrosa," Jurnal Teknologi, vol. 1, pp. 78-84, 2010.

[15] H. G. Schlegel, and K. Schmidt. 1994. Mikrobiologi Umum. Yogyakarta: Gajah Mada University Press, 1994. 